\title{
The Belt and Road Initiative
}

\author{
China's New Geopolitical \\ Strategy?
}

Zhang Zhexin

\begin{abstract}
Since its launch in late 2013, China's Belt and Road Initiative (BRI) has achieved many tangible results that may have lasting effect on the social and economic development of host countries and on the geopolitical dynamics of the world. Its emergence in international political discourse is changing the basic thinking and logic of traditional geopolitical competition. While Western countries tend to interpret the BRI as part of China's hidden geopolitical strategy to ultimately rule the world, Chinese and most developing nations see it as China's international cooperation strategy to enhance global connectivity, communication and cooperation, so as to foster a more balanced and equitable world system. To maintain a favorable international environment for further progress of the BRI, China needs to better explain the details concerning the initiative
\end{abstract}

Zhang Zhexin is Research Fellow at the Shanghai Institutes for International Studies and a non-resident fellow at the Charhar Institute. He is also Deputy Editor of the China Quarterly of International Strategic Studies. His mailing address is: 195-15 Tianlin Road, Shanghai 200233, China. He can also be reached at zhangzhexin@siis.org.cn.

This article is based on a draft paper presented on the 12th Berlin Conference on Asian Security (BCAS) held by Stiftung Wissenschaft und Politik (SWP) on October 15-16, 2018.

(C) 2018 World Century Publishing Corporation and Shanghai Institutes for International Studies China Quarterly of International Strategic Studies, Vol. 4, No. 3, 327-343

DOI: 10.1142/S2377740018500240

This is an Open Access article, copyright owned by the SIIS and WCPC. The article is distributed under the Creative Commons Attribution 4.0 (CC BY-NC) Licence. Further distribution of this work is permitted, provided the original work is properly cited and for non-commercial purposes. 
as well as its role in the country's grand strategy of peaceful development. Meanwhile, China must keep striving to match its words with its deeds in global arenas, so as to win more trust and support from the international community in jointly implementing the initiative.

Keywords: Belt and Road Initiative (BRI); grand strategy; geopolitical competition.

Launched in 2013, China's Belt and Road Initiative (BRI), also known as "One Belt, One Road (OBOR)," has been regarded by many China observers as China's new geopolitical strategy aimed at extending its sphere of influence, fostering new norms of international economic cooperation, and promoting a new world order. ${ }^{1}$ Whilst the Chinese government and academia continually advocate for the initiative, the United States, the European Union and some of China's close neighbors are also deliberating their own blueprints to increase engagement in regional economy and security, further strengthening people's impression of ever more intense geopolitical rivalry, especially in the Indo-Pacific region.

To what extent has the international community overreacted to (or over-expected from) the BRI? More specifically, is the BRI China's new geopolitical strategy? If not, what is its real aim? And what is China's international strategy today? Beginning with a brief introduction into the background of the launch of the BRI, this paper analyzes the strategic dimensions of the BRI as well as its expected role in China's grand strategy. It then examines the potential prospects of the BRI and concludes by discussing the geopolitical implications of the BRI to the world.

\footnotetext{
${ }^{1}$ See, for example, Hugh White, “China's Belt and Road Initiative to Challenge US-led Order," East Asia Forum, May 8, 2017; Alessia Amighini, ed., China's Belt and Road: A Game Changer? (Novi Ligure: ISPI, 2017); and Carlo Muñoz, “China's One Belt One Road Economic Investment also Expands Military Footprint," The Washington Times, April 18, 2018, https://www.washingtontimes.com/news/2018/apr/18/china-military-ambitions-seen-onebelt-one-road/. For more comprehensive and impartial analysis, see David Wijeratne, Mark Rathbone, and Gabriel Wong, "A Strategist's Guide to China's Belt and Road Initiative," PwC Strategy+Business, January 22, 2018, https://www.strategy-business.com/feature/A-Strategists-Guide-to-Chinas-Belt-and-Road-Initiative.
} 


\title{
The BRI in Geopolitical Perspective
}

The Belt and Road Initiative refers to the "Silk Road Economic Belt (SREB)" and the "21st-Century Maritime Silk Road (MSR)" proposed by Chinese President Xi Jinping in September and October 2013 respectively. According to China's White Paper issued in March 2015, the BRI aims to

\begin{abstract}
... promote the connectivity of [the] Asian, European and African continents and their adjacent seas, establish and strengthen partnerships among the countries along the Belt and Road, set up all-dimensional, multi-tiered and composite connectivity networks, and realize diversified, independent, balanced and sustainable development in these countries. $^{2}$
\end{abstract}

Elaborating on five priority areas (policy coordination, facilities connectivity, unimpeded trade, financial integration, and people-to-people bond, later called the "five connectivities"), the White Paper emphasizes that it is "an ambitious economic vision [highlighting by the author] of the openingup of and cooperation among the countries along the Belt and Road." ${ }^{3}$

Grandiose as it appears, the BRI was a

The BRI started as a vague concept on international cooperation. vague concept in the first place, manifesting a political willingness to strengthen cooperation with neighboring countries rather than that of carefully deliberated goals and approaches. That is why the SREB and the MSR were first proposed separately in Kazakhstan and Indonesia, ${ }^{4}$ rather than as a

2“Vision and Actions on Jointly Building Silk Road Economic Belt and 21st-Century Maritime Silk Road," jointly issued by the National Development and Reform Commission, Ministry of Foreign Affairs, and Ministry of Commerce of the People's Republic of China, with State Council authorization, March 28, 2015, https://www.fmprc.gov.cn/ce/cevn/chn/ sghkt/t1251121.htm.

${ }^{3}$ Ibid.

${ }^{4} \mathrm{Xi}$ Jinping proposed the "21st-Century Maritime Silk Road" on his state visit to Indonesia, celebrating the 10th anniversary of the Sino-ASEAN strategic partnership and calling for deeper cooperation between both sides. No other party was mentioned as a potential partner in building the MSR. 
complete package on broader platforms like the Shanghai Cooperation Organization (SCO) summit or East Asian Summit (EAS).

As per tradition of the Communist Party of China (CPC), every new leadership would put forward an updated international strategy (though seldom a conspicuous departure from the previous one), or at least new visions or slogans, based on a comprehensive assessment of the new domestic and international environments facing China. Xi Jinping was no exception. After he was elected Secretary-General at the 18th CPC National Congress in November 2012 (he did not become President of China until March 2013), China's strategic circle came to believe that China was confronted by three major challenges: the first was industrial overcapacity and weakening momentum for high-speed economic growth, necessitating broader international cooperation for larger overseas markets; the second was the slackening world economy and potential retrogression of globalization, which triggered a new round of regional or subregional cooperation such as the Regional Comprehensive Economic Partnership (RCEP); and the third was the Obama administration's AsiaRebalancing strategy which effected a strategic alienation between China and many of its neighbors including Japan, Vietnam and the Philippines, among others.

It was against this background that $\mathrm{Xi}$ proposed the SREB and the MSR, in order to seek new ways of international economic cooperation and thereby mitigate tensions in its neighborhood; this was consistent with China's "peaceful development" strategy during the preceding decade. It was only at the Central Meeting on Neighborhood Diplomacy held in October 2013 that the BRI was mentioned as a combined initiative (albeit with few concrete steps for implementation,) and later written into the document of the 3rd Plenary Session of the 18th CPC National Congress. ${ }^{5}$ As a Chinese BRI expert observes, "While the year of 2013 marks the proposal of the BRI, 2014 witnesses careful policy deliberation of it, 2015 highlights top-level designing, and 2016 marks substantial international

5“Toushi Xijinping Zhoubian Waijiao Linian: Qinchenghuirong Dazao Mingyun Gongtongti [Xi Jinping's Thinking on Neighborhood Diplomacy: Building a Community of Common Destiny with Amity, Sincerity, Endeavor toward Mutual Benefit, and Inclusiveness]," People.cn, October 10, 2014, http://politics.people.com.cn/n/2014/1010/c1001-25805455.html. 
consensus through the launch of landmark projects." ${ }^{6}$ That the BRI was mentioned both domestically and to the world even before a vague blueprint was on hand is a rare case in China's international behavior, which set the stage for both over-expectation and over-caution within the international community afterwards.

\section{The BRI is China's} international

cooperation strategy

rather than

geopolitical strategy.

Five years after its announcement, the BRI has become China's major international cooperation strategy to serve its economic development. So far, China has signed cooperation agreements with over 100 countries and international organizations. More importantly, the BRI has witnessed concrete and steady achievements in infrastructure building, trade and investment promotion, joint construction of industrial parks and free trade zones, financial cooperation and cultural exchange that contribute to economic and social progress of both China and cooperating countries. ${ }^{7}$ As the first initiative proposed by a developing country for global economic cooperation, the BRI marks the strong willingness of the Chinese leadership to kick off a new round of reform and opening-up, to be more deeply engaged in the world economy, and to enhance China's role in global economic and political arenas.

Does the BRI carry any geopolitical weight then? The answer is a definite yes. As discussed above, a major consideration behind its proposal is to mitigate tensions and enhance mutual trust with neighboring countries, so as to ensure a peaceful environment for China's development. For it is believed that closer economic ties and people-to-people bonds help to dissolve hostility and promote security cooperation. In this sense, the BRI is

6“Wudong de Shuangyi Fengshuo de Chengguo - 'Yidaiyilu' Jianshe Huimu yu Yuanjing [Flapping Wings, Bountiful Harvest - Reflections and Visions of Construction of the 'Belt and Road']," Xinhua, January 3, 2017, http://www.xinhuanet.com//politics/2017-01/03/ c_1120233965.htm.

7“'Yidaiyilu' Wuzhounian: yu 103ge Guojia he Guojizuzhi Qianshu 118fen Hezuoxieyi [Five Years after Proposal of the BRI: 118 Cooperation Agreements Signed with 103 Countries and International Organizations]," Sohu News, August 28, 2018, http://www.sohu.com/a/ 250533585_160320. 
conducive to maintaining favorable strategic space for China's long-term development.

However, it is not meant to expand China's "sphere of influence," nor as a geopolitical strategy to compete with the United States or any other country for regional dominance. First, the ultimate goal of the BRI has been set to promote common development on the principles of engagement out of free will and consultation on equal footing, rather than to seek power or control via a state-centered approach. ${ }^{8}$ Second, the BRI has been focused on specific business or social projects to enhance economic and social ties (the "five connectivities") instead of geostrategic elements such as political and security cooperation. Third, the BRI is an open and inclusive mechanism on the principles of "wide consultation, joint contribution and shared benefits." It welcomes all willing countries including the United States - to participate and has generally adopted common international rules and norms while engaging funds, technology and talents from the world. Thus, it can be said that the BRI is China's international cooperation strategy with potential geopolitical implications, instead of a new Marshall Plan, for it neither aims to foster an exclusive economic block nor involves coerced institutional change in participating countries.

\section{China's Grand Strategy Revisited}

Since its reform and opening-up four decades ago, China's "grand strategy" has always been centered on self-development, with quantifiable goals on GDP growth and public living standards set and met every one or two decades. Accordingly, its international strategy — from re-engagement with the global system in the 1980s and 1990s to highlighting peaceful development since the 2000s — has been to serve its domestic development by maintaining a peaceful and cooperative international environment, especially stable relationships with other major powers. The Beijing Olympics and China's robust response to the 2008 global financial crisis greatly boosted China's own confidence as well as expectations from the

${ }^{8} \mathrm{C}$. Flint and Zhang Xiaotong, "The Belt and Road and the Innovation of Geopolitical Theory," Foreign Affairs Review, 2016, 33(3), pp. 1-24. 
international community for China to play a bigger role, and thus China's fundamental principle began to shift from focusing on "keeping a low profile" to "playing a more active role in international arenas."

\section{China's grand} strategy still aims at peaceful development apart from minor changes in tone.

Although China's international strategy retains the paramount goal to maintain a favorable environment for the nation's peaceful development, it does manifest some new features and trends. As mentioned in my 2016 paper, China's international strategy under President Xi had taken full shape by 2015, demonstrating five major changes from the past decades: (1) promoting regional peace and stability pro-actively and with more resources invested; (2) seeking to build new type major-power relations with more pragmatic endeavors; (3) highlighting neighboring diplomacy as the centerpiece of its global strategy; (4) increasing its sense of international contribution and responsibility in providing global public goods; and (5) safeguarding its core interests with greater resolution and harsher efforts. ${ }^{9}$

In general, the new Chinese international strategy features more confidence and determination in safeguarding China's perceived core interests, and stronger steps toward achieving the century-long ambition of "the great rejuvenation of the Chinese nation;" yet at the same time, it also features a more active and responsible role for China in maintaining global peace and stability as well as enhancing regional economic integration. ${ }^{10}$

From the geopolitical lens, faced by increasing challenges to AsiaPacific peace and stability, China has taken active measures to improve its security environment and to foster a lasting and commonly beneficial regional security order - based on the "New Asian Security Concept"

${ }^{9}$ Zhang Zhexin, “Xi Jinping's International Strategy and Its Implications for Southeast Asia," in Malcolm Cook and Daljit Singh, eds., Southeast Asian Affairs 2016 (Singapore: ISEAS, 2016), pp. 55-66.

${ }^{10}$ Ibid. 
proposed by President $\mathrm{Xi}$ on the Hague Nuclear Security Summit in March $2014 .{ }^{11}$ Though no official blueprint has been made by the Chinese government, it has reiterated its vision to push forward an all-inclusive and comprehensive platform for enhanced collective security driven by major powers on their consulted consensus, a "consultative-cooperation approach" that incorporates efforts on mutual trust building and socio-economic integration. ${ }^{12}$ It is in this regard that the BRI serves as an important part of China's international strategy.

Undoubtedly, China's ultimate goal is to become the strongest power and arrive at the center of the world stage, the so-called "China Dream." However, it is not a hegemonic dream, but one of a Confucian nature, which highlights a peaceful, consultative and commonly beneficial approach toward building a harmonious world. That is the essence of President Xi's advocation for all nations to work together to foster a "community of shared future for mankind." With regard to the growing trends of populism and nationalism worldwide, exemplified by Brexit and President Trump's "America First" doctrine, China's BRI and other efforts to strengthen international cooperation are not only conducive to China's economy and global status, but they also help stabilize the global economic and political situation, which, in turn, is beneficial to China's development. Therefore, the BRI is generally viewed by the Chinese strategic circle as key to opening a "window of strategic opportunity" for China's peaceful development. ${ }^{13}$

Why, then, has the BRI triggered much global suspicion about China's "hidden geopolitical agenda"? There are mainly three reasons. First is the ambiguity of the BRI's goals and approaches. As no clear blueprint to implement the BRI has been announced years after its proposal, there are

${ }^{11}$ For a detailed explanation of the concept, see Yang Jingjie, "Xi Elaborates on Nuclear Security Concept," Global Times, March 25, 2014, http://www.globaltimes.cn/content/ 850577.shtml.

${ }^{12}$ Zhang Zhexin, "China's Pursuit of a New Asia-Pacific Security Architecture: Underlying Rationale, Ongoing Actions, and Future Prospects," China Quarterly of International Strategic Studies, 2015, 1(4), pp. 573-590.

${ }^{13}$ Shi Yinhong, "Guanyu Xinshidai Zhongguo Duiwaizhanlue de Ruogan Wenti [Key Questions Concerning China's External Strategy in the New Era]," China Institute for Innovation \& Development Strategy, May 25, 2018, http://www.ciids.cn/content/2018-05/25/ content_17431120.htm. 
many interpretations to the BRI's nature even within the Chinese strategic and academic circle. According to statistics, nearly 49,000 academic articles on the BRI were published between 2014 and 2017, giving different definitions to the BRI, whether as an "initiative," "strategy," or "policy."14 In fact, there was such widespread misunderstanding about the BRI that China's state-run Xinhua News Agency had to issue an executive order in 2017 banning the use of "BRI strategy" in all public media outlets. Still, there are many academic and media articles discussing the "geopolitical significance of the BRI," which adds to the doubt of the international community.

\section{Much global}

suspicion arises from the ambiguity of the BRI.

The second reason lies in the ostensible gap between China's pacifist rhetoric and assertive behavior in recent years. As Professor Shi Yinhong, a leading Chinese strategist, observes, President Xi's leadership seems to have put forward two contradictory sets of messages in its words and actions: one highlights China's "peaceful development" orientation, sincere efforts to build a "new type of great-power relationship" with the United States and work more closely with it in tackling salient security issues concerning North Korea, Syria, and Iran, as well as concrete measures to implement its "good neighbor policy," especially with the Association of Southeast Asian Nations (ASEAN); the other, however, suggests that China is taking a more assertive line, including, among others, a shift in the driving aim of the People's Liberation Army (PLA) from military modernization to "being capable of fighting, and fighting victoriously", high-profile reports on new breakthroughs in China's military build-up, and a hardening stance with regard to its territorial and maritime disputes with neighboring countries. ${ }^{15}$ As China's economic and military strength continues growing rapidly, it is natural for other countries to attach geopolitical implications to any of China's major moves - not only the BRI, but also the Asian Infrastructure Investment

${ }^{14}$ Liu Weidong et al., "Progress in Research on the Belt and Road Initiative," Acta Geographica Sinica, 2018, 73(4), http://aoc.ouc.edu.cn/36/df/c9821a210655/page.htm.

${ }^{15}$ Shi Yinhong, "China's Complicated Foreign Policy," European Council on Foreign Relations, 31 March, 2015, http://www.ecfr.eu/article/commentary_chinas_complicated_foreign_ policy311562. 
Bank (AIIB), the Regional Comprehensive Economic Partnership (RCEP) and other economic initiatives.

The third reason is related to the "neo-colonialism" discourse surrounding the potential outcomes of the BRI. It is often argued that by increasing national debt burdens and making those less successful developing nations an import market of Chinese goods, the BRI is consolidating China's economic and political dominance in Asia and Africa, thus extending its sphere of geopolitical influence. ${ }^{16}$ As discussed above, the BRI is an inclusive economic mechanism to promote common development through consultation and joint efforts, instead of self-interested exploitation and one-way flow of technology and wealth. The overwhelming enthusiasm of developing countries in the BRI, as seen on the first "Belt and Road Forum for International Cooperation" held in May 2017, is sufficient to invalidate the "neo-colonialism" argument.

In short, the BRI is an important part of China's international strategy to secure a favorable environment for lasting development, which is crucial to achieve its grand strategic goal: to continue developing peacefully and become a truly great power with international recognition. Compared with the militant and/or mercantilist approaches of rising powers in history which built their wealth and glory upon conquests, exploitation of colonies, or monopoly of certain strategic resources, China's BRI - open, inclusive, and focused on enhancing communication and connectivity for common development - is consistent with the guiding principle of the nation's international engagement over the past decades, embodied in its ever stronger advocacy for building a "community of shared future for mankind" with other nations.

\section{Future of the BRI and Its Geopolitical Implications}

Although the Chinese government has increasingly clarified the objective, principles and road map of the BRI, and a large number of joint projects are

\footnotetext{
${ }^{16}$ See, for example, Jean-Marc F. Blanchard, "Revisiting the Resurrected Debate About Chinese Neocolonialism," The Diplomat, February 8, 2018, https://thediplomat.com/2018/ 02/revisiting-the-resurrected-debate-about-chinese-neocolonialism/; and Tridivesh Singh Maini, "Debt-Trap: China's Invisible Hand Behind the BRI," The Geopolitics, July 7, 2018, https://thegeopolitics.com/debt-trap-chinas-invisible-hand-behind-the-bri/.
} 
underway to enhance economic and social ties between China and BRIcovered countries, many Chinese scholars consider the BRI premature not only because China still lacks economic strength and soft power to lead such a grand initiative, but more importantly, because it will inevitably aggravate the "China threat" mentality and invite more balancing, if not containing, moves from the United States and other major powers. A better way to maintain a favorable international environment, they argue, is to keep a low profile in international arenas while promoting regional integration by bilateral or mini-multilateral approaches, so as to avoid the "over-extension" of Chinese influence. ${ }^{17}$ Other opponents tend to consider the potential economic costs of the BRI and doubt whether its costs will prove bigger than its benefits, including geopolitical ones, to China's longterm development.

\section{The overall benefits of the BRI to China} are yet to be seen.
Indeed, it is sensible for a country to sacrifice short-term economic benefits for long-term strategic interests, as China would very possibly do in making deals with potential partners. ${ }^{18}$ But how can China ensure the calculations are correct? Though the Chinese government has reiterated that the BRI is not only China's "baby," most other developing nations, especially African ones, look to China for more financial and technological aid, which arouses much debate in Chinese society on whether China should make so much commitment to other countries while its own population is still faced by such serious problems as poverty, underemployment and lack of funding for private enterprises. It is very likely that with the shrinking financial basis of state expenses due to slower economic growth and more intense trade disputes with the United States, the Chinese government will have fewer resources to drive the BRI as fervently as before, which may undermine the willingness of other countries to continue participating in the initiative.

${ }^{17}$ Yin Ruilin, “Guoli guodu yanshen de daguo xingshuai qishilu [Implications of Overextension of National Strengths to the Rise and Fall of Great Nations]," United Morning Post, May 24, 2018, http://www.zaobao.com/wencui/politic/story20180524-861611.

18“'Yidaiyilu' Bufen Yanxian Guojia dui Zhongguo Tichu Gengkeke de Youhuitiaojian [Some BRI-covered Countries Raise Harsher Requests to China on BRI Cooperation]," Huanqiu Strategic Thinktank, July 26, 2018, http://www.yidianzixun.com/0JdXSbHj. 
Moreover, during the past five years, the BRI has encountered a fair share of challenges and setbacks: suspended projects due to leadership or policy change of host countries, such as the Singapore-Malaysia High-speed Rail project and the East Coast Railway project in Malaysia; postponed projects due to inadequate environmental or social considerations, such as the Myitsone dam in Myanmar and China's "High-speed train for rice" project with Thailand; troubled projects due to local security risks, such as the oil and natural gas pipelines between China and Myanmar; and terminated projects due to exposed corruption, such as the road construction project along the China-Pakistan Economic Corridor (CPEC). As former Chinese UN ambassador Sha Zukang warns, if these problems are not addressed effectively, we may possibly see much corruption, violation of local law, degradation of local environment, frequent strikes and public demonstrations, even Chinese-targeted terrorist attacks along the Belt and Road in 10 to 20 years. ${ }^{19}$

Yet the biggest challenge to the BRI may lie in its "grandness." Today, nearly every economic and social cooperation plan between China and Asian, European, African and Latin American countries is labeled as a BRIrelated project, so as to gain more state resources and leadership attention; even China's proposal to explore a new trade route through the Arctic is named "Polar Silk Road (PSR)," or "Silk Road on the Ice." This has attached too much weight and expectations to the BRI, where any major failure in specific projects would damage people's confidence in the whole BRI. As a trade war and even "new Cold War" is looming between China and the United States, China is bound to face more economic protectionism from the world. If it fails to stabilize its economic relationship with the United States and to launch a new round of comprehensive opening-up in a timely and resolute manner, then the BRI will inevitably encounter greater resistance from Western and developing countries alike.

Despite the daunting challenges ahead, the BRI continues to gather momentum and strengthen China's regional influence as well as international status.

A major challenge to the BRI lies in its grandness.

19“Sha Zukang: 'Yidaiyilu' Yanjiu Kande Bawo Jisile [Sha Zukang: I am So Worried about Our 'Belt and Road' Research]," Phoenix News, July 18, 2017, http://news.ifeng.com/a/ 20170718/51453071_0.shtml. 
Economically, a number of joint infrastructure projects have been underway, such as the Mombasa-Nairobi railway, the Jakarta-Bandung high-speed railway, the road construction project along the China-Pakistan Economic Corridor (CPEC), and the Heihe highway bridge linking China and Russia. China has also opened hundreds of new air, land and sea routes to BRI-covered countries over the past five years. These projects and routes not only promote financial and technological cooperation between China and host countries for now, but they will greatly enhance their trade and economic partnerships in the long run. As evidence, China's trade volume with BRI-covered countries reached US $\$ 1.44$ trillion in 2017, an increase by 13.4 percent from the previous year and 5.9 percent point higher than the growth rate of China's total foreign trade; by June 2018, China has reached agreement with seven BRI-covered countries on the arrangement of RMB clearing ${ }^{20}$ further enhancing the internationalization of the RMB.

In the political aspect, China has reached cooperation agreements with over 90 national governments on building the BRI, and they have jointly issued many concrete plans to realize the agreements, such as the Strategic Planning 2030 on Communications in the Greater Mekong Sub-region, Railway Development Strategy 2030 for Central Asian Economic Cooperation, and ChinaASEAN Strategic Plan on Communications Cooperation. ${ }^{21}$ Meanwhile, China has signed 76 bilateral cooperation documents on culture and tourism with BRI-covered countries and established 16 cultural centers in those countries, which had hosted more than 1,600 events by mid-2018. ${ }^{22}$ Closer policy coordination and people-to-people bonds will naturally contribute to a more stable and favorable international atmosphere for future progress of the BRI; equally importantly, they help improve China's neighboring relationships, especially with Japan, India, Vietnam, and the Philippines, which

20"Yidaiyilu' Wunian Chengjiu Huihuang [Great Achievements of the BRI in the Past Five Years]," Xinhua, August 17, 2018, http://www.xinhuanet.com/politics/2018-08/17/ c_1123287186.htm.

21 “Liantong Gongtong Fanrong de Fazhan Zhilu — Gongjian 'Yidaiyilu' 5nian Chengguo Zongshu [Road to Common Prosperity - A Summary of the Joint Achievements in Building the BRI]," Xinhua, August 14, 2018, http://world.people.com.cn/n1/2018/0814/c100230228261.html.

22 "Factbox: People-to-People Exchange Achievements along Belt and Road," Xinhua, August 28, 2018, http://www.china.org.cn/china/Off_the_Wire/2018-08/28/content_60700032. htm. 
were involved in harsh disputes with China over territorial disputes only a few years ago.

From a military perspective, many Western observers worry that China's heavy investment in the building of more than 40 seaports in 34 countries - such as the Port of Piraeus in Greece, the Hambantota Port in Sri Lanka, and the Gwadar Port in Pakistan - will end in its control of these ports due to growing financial dependence of the host countries on China, helping realize its "String of Pearls" strategy for the Indo-Pacific. ${ }^{23}$ Although such worries are unfounded - the Chinese government has never come to the thought of establishing overseas naval bases, nor would any host country allow China's absolute control of its seaports and thus become a frontline for major-power confrontation, China has indeed used many of those seaports for naval supplies on commercial escort and international peace-keeping missions in the past years. As China's navy continues growing and conducts more overseas exercises, the military significance of those seaports will become more prominent. The long-term security implication of the BRI, however, lies in its potential to help strengthen security cooperation between China and BRI-covered countries and thus foster new security mechanisms outside of the U.S. dominance.

The most profound implication of the BRI to global geopolitics may be its emergence in international political discourse, thereby forging new thinking on the way nation states develop and interact with each other. In NoThe BRI may change the dynamics of global geopolitics. vember 2016, the BRI was first mentioned in a United Nations resolution (A/RES/71/9) adopted by the General Assembly, urging "further efforts to strengthen the process of regional economic cooperation, including measures to facilitate regional connectivity, trade and transit, including through regional development initiatives such as the [Belt and Road] ${ }^{24}$ to help ameliorate the situation in Afghanistan. This marked

${ }^{23}$ For instance, see U.S. Senators David A. Perdue and Patrick Leahy's letter to U.S. Secretaries of the Treasury and of the State, August 3, 2018, https://www.perdue.senate.gov/imo/ media/doc/IMF\%20China\%20Belt\%20and\%20Road\%20Initiative\%20Letter.pdf.

${ }^{24} \mathrm{UN}$ Resolution A/RES/71/9 adopted by the General Assembly at its 47th plenary meeting, November 17, 2016, http://www.un.org/en/ga/search/view_doc.asp?symbol=A/ RES/71/9, p. 12. 
the beginning of international endorsement of the BRI's potential role in mitigating tensions, either within a country or between competing nations, and consolidating peace through closer communication and economic cooperation. If geopolitical game among major powers tends toward competition for inclusive economic partnerships and engagement in bringing about higher connectivity, rather than arms race, sphere of influence, and exclusive political or military blocks, then the whole logic of global geopolitics may change for all, leading to a more balanced and equitable international system without major-power dominance and manipulation.

It at least in part explains why many Western countries - as vested interest-holders of the international system after the Cold War - have been increasingly worried about China's BRI and counter-proposed their own strategies on regional cooperation. While the United States proposed an "IndoPacific Initiative" in July 2018, supported by Japan, Australia and some other countries, the EU also issued a new Asia connectivity strategy with an expected starting fund of 60 billion Euros, dubbed as the EU version of the Belt and Road, which is widely considered as a counterbalance to China's BRI. ${ }^{25}$

Even so, such economic cooperation-centered initiatives should be encouraged, for they are helpful to regional integration and development while alleviating financial pressure on China to single-handedly drive infrastructure building in Asia. It will be more beneficial to all parties if China, the United States, the EU and other major countries can reach a consensus on their respective role and commitment so as to avoid waste and counteraction among themselves.

If such moves are meant to confine China's expanding geopolitical influence through the BRI, however, it would be of little meaning, not only because neither the United States nor the EU has the same state-backed financial resources as China for lasting investment in infrastructure building in Asia, but more importantly, because they will amplify the geopolitical tensions between China and the West and cause more instability in regional politics and economy, which will bring about economic losses and unexpected security challenges to all parties involved.

${ }^{25}$ Erik Brattberg and Etienne Soula, “Europe's Emerging Approach to China's Belt and Road Initiative," Carnegie Endowment for International Peace, October 19, 2018, https:// carnegieendowment.org/2018/10/19/europe-s-emerging-approach-to-china-s-belt-and-roadinitiative-pub-77536. 


\section{Conclusion}

The BRI is a significant human attempt to strengthen world connectivity and enhance communication and cooperation among nations, especially in view of the rising protectionism and unilateralism in the United States and some other major countries. Since many aspects of the BRI remain vague thus rendering it a hot topic for debate - to many China observers even five years after its launch, it is of urgent necessity for China to face up to the prevalent doubts and concerns of the international community about the BRI, in order to win more understanding and support for this momentous global project.

First, as the designer and ultimate driver of the BRI, China should present to the world more facts and concrete examples about BRI projects in host countries (both successes and failures), so as to gear the focus of global debate from such conjectures as whether the BRI epitomizes China's new ambition to rule the world onto more specific calculation of the BRI's effect on the host countries and the global economic system. A good example is the research done by the World Bank, which shows that the BRI will significantly reduce shipment times and trade costs for BRI economies (up to 3.2 and 2.8 percent, respectively) and for the world as a whole (up to 2.5 and 2.2 percent, respectively). ${ }^{26}$ Such concrete data speak much louder than stereotyped policy statements.

Meanwhile, China needs to do more explaining of what the BRI is, instead of arguing what it is not. This requires more in-depth study into the "proto-theory" behind the BRI, such as the Confucian theory of "great harmony of the world" and its modern version of "community of shared future for mankind," social theory of international relations highlighting de-centralization of global power and network building of global partnerships, and other theories on globalization and global governance. By far, the Chinese academia has already begun with such efforts and produced some valuable thinking in this regard. ${ }^{27}$

${ }^{26}$ Francois De Soyres, Alen Mulabdic et al., How Much Will the Belt and Road Initiative Reduce Trade Costs? (Washington, D.C.: World Bank Group, October 2018), p. 31.

${ }^{27}$ See, for instance, Zhao Lei et al., “'Yidaiyilu Xuyao 'Yuanlilun' [The BRI Needs ProtoTheory]," Belt and Road 100 Forum, December 5, 2018, http://obor100.com/forum.php? $\bmod =$ viewthread\&tid $=5939$. 
Most importantly, China should keep striving to match its words with its deeds on global arenas. More people have acknowledged China's constructive role in global climate and economic governance because it has shown significant effort and made tangible sacrifices. Likewise, the international community will embrace the BRI with more trust and enthusiasm if China shows more enterprise in pursuing peaceful development and providing global public goods. Fortunately, China's recent moves - such as accelerating its opening-up and domestic economic reform, tuning down on its centennial goal to "rejuvenate the Chinese nation," strengthening negotiation and cooperation with disputant neighboring countries like Japan, Vietnam and the Philippines, and pumping more investment and other national resources into the BRI regardless of various temporary difficulties - all seem to demonstrate China's sincerity and determination to push forward this ambitious project, which is designed not upon geopolitical considerations, but on the ideal of creating a new cooperative mechanism that can truly benefit the world population in the long run. 